\title{
ASPECTOS VIDEOLAPAROSCÓPICOS DE ENDOMETRIOSE PÉLVICA
}

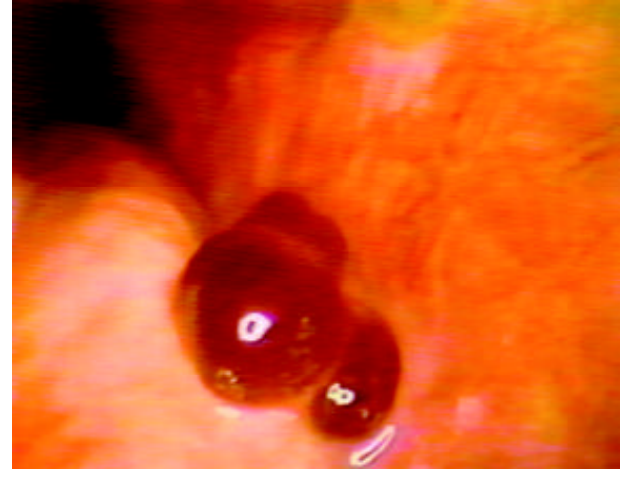

Imagem videolaparoscópica de lesão de endometriose peritoneal (lesão em pólipo avermelhado)

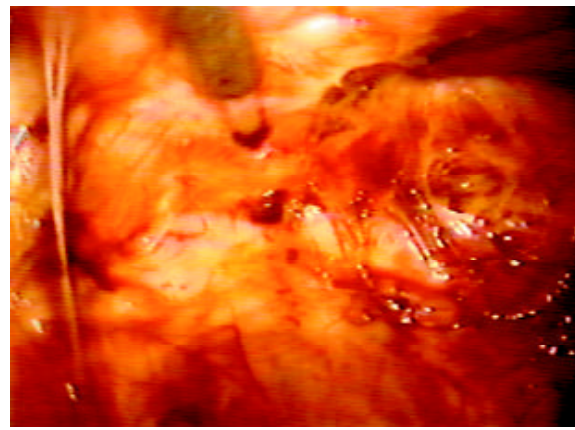

Imagens videolaparoscópicas de endometriose do septo reto - vaginal

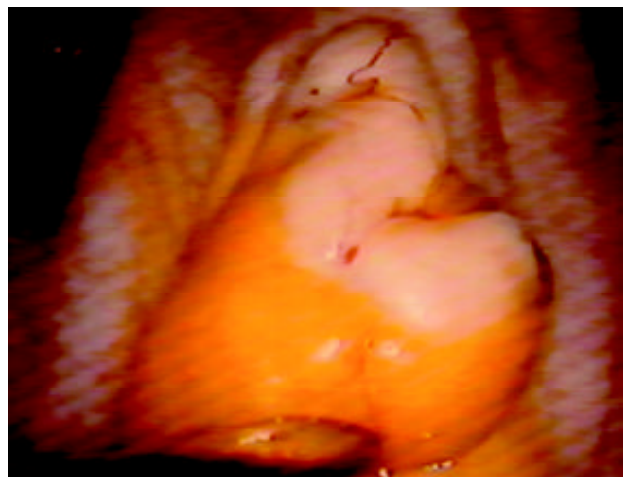

Imagem videolaparoscópica de endometriose de apêndice cecal

A endometriose do septo retro-vaginal classifica-se em 3 tipos: Tipo I, quando o maior diâmetro da lesão está na superfície; Tipo 2, quando o sigmóide adere ao septo retro-vaginal; Tipo 3, quando o maior diâmetro da lesão encontra-se na profundidade. 